\title{
WHERE IS THE SPEECH THAT MATTERS? ON THE SILENCE OF THE CZECH THEATRE PROFESSIONALS IN A CRISIS
}

\author{
JAN MOTAL \\ Theatre Faculty, Janáček Academy of Music and Performing Arts in Brno, \\ Czech Republic
}

\begin{abstract}
The essay presents the thesis that despite their activist tradition, Czech theatres abandoned any social criticism during the COVID-19 pandemic because they were unable to speak publicly about the structural conditions of the crisis (overtourism, mobility, etc.) and possibilities for change. The author argues that it is because the language of theatre professionals is nowadays shallow and clichéd and serves rather as a strategy to secure the positions in the artistic field than the true speech capable of addressing the public. This situation is interpreted in terms of neoliberalism/capitalist realism (Mark Fisher) producing the pragmatic language incapable of imagination and transformation. The intellectuals' speech of transcendentals (detached from the reality) is contrasted with true speech (Martin Buber, François Laruelle) originating in immanence. The artists are depicted as the keepers of personal, archetypal language capable of producing universal ("terrestrial" - Bruno Latour) images of utopia. This is discussed especially in the context of the environmental crisis.
\end{abstract}

Keywords: capitalist realism, neoliberalism, ecocriticism, pandemic, public sphere, intellectual, political theatre, risk society, language.

An influential Czech theatre magazine Svět a divadlo [The World and Theatre] organizes the annual ceremony of The Theatre Critics' Award. In 2020, the awards were severely affected by the COVID-19 pandemic. During spring, all Czech theatres were closed just as all other institutions were, because of the drastic (even though necessary) precautions imposed by the Czech government. Due to this extraordinary situation (which I am to call "the crisis" from now on) even the awards ceremony was postponed. ${ }^{1}$ The second issue of the magazine run interviews with the awards' laureates. One of the questions asked was: "Do theatres have a chance to survive a longer period in the quarantine?" Musician and composer Tomáš Vtípil answered: "This is a question of the definition of theatre. Will there be anything left if it is freed from the pressure to be 'produced'? Now we are going to see whether it is mainly a flow heater, into which larger or smaller amount of energy, finances and prestige are poured and better a worse art leaks out, or whether it possesses another (social, ideological, spiritual,... ) content that keeps the people together." ${ }^{2}$ That is an accurate observation expressing the nature of the crisis. When theatres are closed and artists' incomes are in danger, what is left of theatre?

\footnotetext{
${ }^{1}$ The ceremony eventually took place in a minimal form, without the presence of both general and professional public, on June 22, 2020, at the Komedie Theatre in Prague.

${ }^{2}$ KRÁL, K. Divadla jsou jako švábi: Anketa s nositeli Cen divadelní kritiky - a nejen s nimi [Theaters are Like Cockroaches: An Interview with the Theater Critics Award Winners - and Not Just with Them]. In Svět a divadlo, 2020, Vol. 31, Issue 2, p. 25.
} 
During the pandemic, Czech theatres did not fulfil their socially critical role. Why did the theatres omit the "social, ideological or spiritual" dimension of art and focused on securing their institutional durée or loyalty to state and status quo rather than on showing how the emergency is conditioned by the socio-economic regime in which we live? Why were the artists silent, even though they did speak in the media? I am to argue that it is because nowadays, they are not capable of true speech, being drowned in the neoliberal or left-liberal newspeak and pragmatism that avoids any serious talk about change and utopia.

I intend to stimulate the artists' endeavour to employ speech that matters and makes them able to address the general public and the outclassed, providing relevant social criticism as well as hope for our common future. Using the term "utopia", I am not advocating any of the "schematic fictions" as Martin Buber says. ${ }^{3}$ I would like to promote the need of the common future, grounded in immanent universality (the uchronia of the Real, as François Laruelle calls it), ${ }^{4}$ leading to the organic growth of the inclusive community (Gemeinschaft) capable of speaking about its perspectives and recognizing the global risks. For me, true speech can spin the bonds of Gemeinschaft and reveal the Real buried under the hegemonic ideology of capitalist realism. ${ }^{5}$ Albeit the Real (the world as it is rather than as we construct it) is "unspeakable"6, artists possess imagination grounded in the (immanent) archetypal universality.? Therefore, they can "speak close by" the Real and transgress the cultural and classrelated particularities. The true speech involves a non-utilitarian, non-commodified language that is not used to gain symbolic power or secure the conquered socioeconomical positions. The Real is "radically immanent", it is "a void of reality" ${ }^{8}$ undermining capitalist realism. This normative understanding of speech presents the framework of my essay.

\section{The Modernism of Our Crisis}

The present-day COVID-19 pandemic is caused not just by the biological perpetrator (SARS-CoV-2); the very structure of late modernity accelerated its spread. The

\footnotetext{
${ }^{3}$ For Martin Buber, utopias are presented either as "schematic fictions" such as in the case of Marxism, which are deterministic and dogmatic, or as "organic planning", oriented towards natural (albeit radical) developing of community. I profess my affiliation to the latter. See BUBER, M. Pfade in Utopia: Über Gemeinschaft und deren Verwirklichung. Heidelberg : Lambert Schneider, 1985, p. 36.

4 "The future does not come out of some temporal transcendence, it comes from the depths of human immanence." LARUELLE, F. Intellectuals and Power. Cambridge : Polity Press, 2015, p. 129 (quotation); p. 143 (uchronia).

${ }^{5}$ For Mark Fisher, capitalist realism is the prevailing atmosphere preventing any radical action because the present-day cultural hegemony is seen as the only possible. One of the strategies on how to compete with this is to invoke the Real(s) (in the Lacanian sense of meaning). This presents the framework for my reflections, considering the non-utilitarian, dialogic speech as the possible means of reaching the goal. FISHER, M. Capitalist Realism: Is There No Alternative? Winchester and Washington : Zero Books, 2009, p. 18.

${ }^{6}$ According to Lacan, the Real is not yet differentiated, it is "without tissue." LACAN, J. The Seminar of Jacques Lacan: Book II: The Ego in Freud's Theory and in the Technique of Psychoanalysis 1954 - 1955. New YorkLondon: W. W. Norton \& Company, 1991, p. 97.

${ }^{7}$ In this essay, I employ the concept of archetypes in the sense of Jungian psychology, particularly how Anthony Stevens defined it in its evolutionary (and therefore universal) manner. See STEVENS, A. Archetype Revisited: An Updated Natural History of the Self. London - New York : Routledge, 2015.

${ }^{8}$ LARUELLE, F. Intellectuals and Power, pp. $98-99$.
} 
environmental catastrophe we are facing in the $21^{\text {st }}$ century is homogenous to the COVID-19 pandemic in many parts of its structure (e. g. mobility, overtourism, business that is reluctant to curtail, conspirations, and others) ${ }^{9}$ As environmental journalist Emily Atkin recently expressed, "it's irresponsible not to [talk about the climate during the coronavirus crisis]". ${ }^{10}$ Although the emergence and spread of new viruses is "natural" in the sense that it is biological, chemical and ecological, humans play a crucial role in the process. The recent health crisis (which did not end and is hardly the last one) informs us that in order to limit pandemics, we have to "decolonize the world". Many experts are calling for a profound transformation of our societies, seeing the coronavirus SARS-CoV-2 as "a warning". The way how politicians decide to stimulate the economy can either amplify or mitigate the global climate threats, and the global society has to negotiate and act. ${ }^{11}$ The current research on COVID-19 and its socio-economic context reveals that the pandemic is just one part of a long chain of emerging and interconnected risks, such as is overtourism and global mobility, gendered work, privileges and inequalities, ecology and even racism and ethnically based medical mistrust. ${ }^{12}$ Naturally, theatres are part of this risk-generating processes as they participate on the globalization, for instance via supporting tourism or international travel. ${ }^{13}$

As Ulrich Beck explains, "in advanced modernity the social production of wealth is systematically accompanied by the social production of risks". ${ }^{14}$ The causes of the risks have to be socially recognized, and subsequently pressured by the massive call for change. The risk producers refute the charges and attempt to bring in other causes and originators. "Access to the media becomes crucial," shows Beck. ${ }^{15}$ Therefore, in the times of crisis, society needs a group of communication professionals, who are able to reveal the social issues in media and promote the change - intellectuals.

\footnotetext{
${ }^{9}$ In April 2020, the heads of French research institutions associated in National Research Alliance for the Environment published an article in Le Monde, which reveals the link between pandemics and ecosystem degradation and calls for action. The arguments are strictly biological. See COLLECTIF. La pandémie de Covid-19 est étroitement liée à la question de l'environnement. In Le Monde, 17. 4. 2020. [online]. [cit. 5 July 2020]. Available at: https://www.lemonde.fr/idees/article/2020/04/17/la-pandemie-de-covid-19-est-etroitement-liee-a-la-question-de-l-environnement_6036929_3232.html.

${ }^{10}$ SEGALOV, M. The Parallels between Coronavirus and Climate Crisis are Obvious [Interview]. In The Guardian, 4. 5. 2020. [online]. [cit. 5 July 2020]. Available at: https://www.theguardian.com/environment/2020/may/04/parallels-climate-coronavirus-obvious-emily-atkin-pandemic.

${ }^{11}$ LAVOCAT, L. Pour limiter les pandémies, les humains doivent «décoloniser le monde» [Enquête]. In Reporterre le quotidien de l'écologie, 28. 3. 2020. [online]. [cit. 5 July 2020]. Available at: https://reporterre.net/ Pour-limiter-les-pandemies-les-humains-doivent-decoloniser-le-monde.

${ }^{12}$ See BENJAMIN, S. - DILLETTE, A. - ALDERMAN, D. H. “We Can't Return to Normal”: Committing to Tourism Equity in the Post-pandemic Age. In Tourism Geographies, 12. 5. 2020; BONCORI, Ilaria. The Never-ending Shift: A Feminist Reflection on Living and Organizing Academic Lives during the Coronavirus Pandemic. In Gender - Work - Organization, 15. 4. 2020; DOBUSCH, L. - KREISSL, K. Privilege and burden of im-/mobility governance: On the Reinforcement of Inequalities during a Pandemic Lockdown. In Gender - Work-Organization, 2020, pp. 1 -8; SCAMBLER, G. COVID-19 as a 'Breaching Experiment': Exposing the Fractured Society. In Health Sociology Review, 2020, Vol. 29, Issue 2, pp. 140 - 148; CROSSLEY, É. Ecological Grief Generates Desire for Environmental Healing in Tourism after COVID-19. In Tourism Geographies, 5. 5. 2020; EGEDE, L. E. - WALKER, R. J. Structural Racism, Social Risk Factors, and Covid-19 - A Dangerous Convergence for Black Americans. In The New England Journal of Medicine, 22. 7. 2020; LAURENCIN, C. T. WALKER, J. M. A Pandemic on a Pandemic: Racism and COVID-19 in Blacks. In Cell Systems, 2020, Vol. 11, Issue 1 , pp. 9 - 10 .

${ }^{13}$ BENNETT, S. Theatre/Tourism. In Theatre Journal, 2005, Vol. 57, Issue 3, pp. 407 - 428.

${ }^{14}$ BECK, U. Risk Society: Towards a New Modernity. London : SAGE, 1992, p. 19.

${ }^{15}$ Ibid., p. 32.
} 
However, in the present-day neoliberalism, the speech is fluid, or postmodern; ${ }^{16}$ it has no personal guarantee as particular subjectivity (albeit it swears on authenticity and individuality) and being inherently utilitarian, it is liable to fashions. The visions of utopia seem to be a mere dream or commodity, as are the lyrics of John Lennon's Imagine on a T-shirt, or as mere means to gain political attention. Capitalist realism suppresses the immanent and inexpressible Real in which we live with a distinct, transcendental, ideologically structured "reality" ${ }^{17}$ The risks in a global society (and pandemic as well) are the Real we have to release from the shackles of silence, before the Real bursts into our "reality" and destroys the world as we know it. To fight for free speech is not enough because the value of freedom is the backbone of neoliberal ideology - culminating in the fable of laissez-faire.

Therefore, we are in need of true speech, oriented towards the public as the community of partners, without clichés and impersonal concepts ("transcendentals"). ${ }^{18}$ Only when we can speak about our world together (Gemeinschaft), transgressing the stylistic (culture- and class-related) differences and abandoning paternalism, we can collectively recognize the risks. ${ }^{19}$ The contrary is impersonal, technical or dogmatic speech incapable of affecting and binding together. That is why the intellectuals as social critics mastering the language (writers, performers, or other) are needed in the times of crisis. Of course, the intellectuals form a "new class" as Julien Benda or Pierre Bourdieu argued, or in the sense of Antonio Gramsci or Michel Foucault, they represent their class of origin. Even if the intellectuals are grounded in the culturally hegemonic class, they are able to transgress $i^{20}-$ and for this purpose they are language experts, being able to use it critically and beyond its prevalent triviality.

According to Edward Said, intellectuals present their concerns before an audience or constituency not only as a matter of what they say but what they are as well - mixing the private and public they appear as persons. ${ }^{21}$ In this sense, not every author is an intellectual in capitalist society. Literature is subject to commodification, standardization and abstraction of subjectivity, becoming a commodity, too (as an exclusive experience). Artists, being intellectuals, have to transgress this degradation of language and restore its relation to the living wholeness of the reality, as Georg Lukács explained. ${ }^{22}$

${ }^{16}$ In its fluidity, depthlessness and paralysis of any negation and revolt. JAMESON, F. Postmodernism, pp. $5-6$.

${ }^{17}$ FISHER, M. Capitalist Realism, p. 18.

${ }^{18}$ BUBER, M. Elemente des Zwischenmenschlichen. In Das Dialogische Prinzip (ed. M. Buber). Heidelberg : Lambert Schneider, 1984, p. 293.

${ }^{19}$ The postmodern emphasis on difference and diversity both in theory and artistic practice, in fact, resists (and even actively struggles) consensus and therefore it hinders any collective action. See JAMESON, F. Postmodernism, or, The Cultural Logic of Late Capitalism. Durham : Duke University Press, 1997, p. 340. Similarly, the concept of "multiculturalism" transforms social conflicts into the question of cultural equality, being merely a technical problem of the (neo)liberal administration. See BOURDIEU, P. - WACQUANT, L. New Liberal Speak: Notes on the New Planetary Vulgate. In Radical Philosophy, 2001, Vol. 105, p. 3; or GANTI, T. Neoliberalism. In Annual Review of Anthropology, 2014, Vol. 43, p. 95.

${ }^{20}$ For this typology see KURZMAN, Ch. - OWENS, L. The Sociology of Intellectuals. In Annual Review of Sociology, 2002, Vol. 28, pp. $63-90$.

${ }^{21}$ SAID, E. Representations of the Intellectual. New York: Vintage, 1994, p. 12.

${ }^{22}$ LUKÁCS, G. Karl Marx und Friedrich Engels als Literaturhistoriker. Berlin: Aufbau Verlag, 1948, pp. $209-210$. 
Theatre professionals, being celebrities, are endowed with specific capital, i.e. the recognisability or "accumulated media visibility" based on recurrent media representations. ${ }^{23}$ It is up to them whether they invest it in a mere circulation of excitement, or they try to transgress it. This celebrity capital could be invested in public advocacy - grounding the speech in a personal guarantee. From this (archetypal and therefore universal) immanency, putting aside all the utilitarian and pragmatic intentions, despite being a member of the elite the intellectual can speak to the oppressed and outclassed - grounding the speech in the shared, rather than (socially and culturally) distinct.

\section{The Czech Myth of Theatre Intellectuals}

Czech theatre professionals frequently present themselves as intellectuals, advocating public issues or even taking part in demonstrations. They usually speak a lot - for instance, at the greatest anti-government demonstrations in the Czech post-1989 era that took place in July 2019 at Letná plain in Prague ${ }^{24}$ many of the popular theatre performers appeared on the stage before the crowds of spectators (around 250000 people participated in the protest), e. g. Daniela Kolárová, Ivan Trojan, Aňa Geislerová, or Zdeněk Svěrák. In the last decades, several Czech artists organized their own public campaigns, such as the video Přmemluv bábu! [Persuade grandma!] produced by actors Jiří Mádl and Martha Issová and directed by recognized director Petr Zelenka. The campaign appealed to young people to persuade their grandparents to vote for right-wing politicians, rather than communists. In 2020, the same actors produced a new video Zachran̆ bábu! [Save your grandma! $]^{25}$ that aimed to encourage young people to help elderly citizens during the pandemic.

These public activities of theatre professionals are in accord with collective national mythology. In Czechia, the theatres are commonly understood as a positive force during a crisis. ${ }^{26}$ The major ground for this anticipation is that the theatres substituted the absent public intellectual community during the totalitarian regime ${ }^{27}$ and were actively engaged in the freedom struggle during the Velvet Revolution (1989). ${ }^{28}$

${ }^{23}$ DRIESSENS, O. Celebrity Capital: Redefining Celebrity Using Field Theory. In Theory and Society, 2013, Vol. 42, Issue 5, p. 552. In accord with Olivier Driessens, I employ the term "celebrity" without negative connotations.

${ }^{24}$ The protest was organized by a public initiative Milion chvilek pro demokracii [The Million Moments for Democracy], led by activist Mikuláš Minář. See: Největší demonstrace od listopadu 1989? Letnou zaplnil protest za nezávislost justice [The Biggest Demonstration since November 1989? Letná was Filled with a Demonstration for the Independence of the Judiciary]. In iRozhlas, 23. 6. 2019. [online]. [cit. 5 July 2020]. Available at: https://www.irozhlas.cz/zpravy-domov/letna-demonstrace-andrej-babis-benesova-milionchvilek-fotky_1906231735_lac.

${ }^{25}$ Jiří Mádl oprášil svou výzvu: Zachraň bábu, zachraň dědka [Jiří Mádl Dusted off his Appeal: Save the Grandma, Save the Grandpa]. In Seznam Zprávy, 17. 3. 2020. [online]. [cit. 5 July 2020]. Available at: https:// www.seznamzpravy.cz/clanek/jiri-madl-oprasil-svou-vyzvu-zachran-babu-zachran-dedka-93824.

${ }^{26}$ See e. g. CHTIGUEL, O. F. Without Theatre, the Czechoslovak Revolution Could Not Have Been Won. In The Drama Review, 1990, Vol. 34, Issue 3, pp. 88 - 96.

${ }^{27}$ BECK, D. C. Divadlo Husa na Provázku and the "Absence" of Czech Community. In Theatre Journal, 1996, Vol. 48, Issue 4, pp. $419-441$.

${ }^{28}$ On November 17, 1989, the theatre community "united in a general strike with the students and independent activists to spearhead the nation's struggle against the despotism of the totalitarian system," 


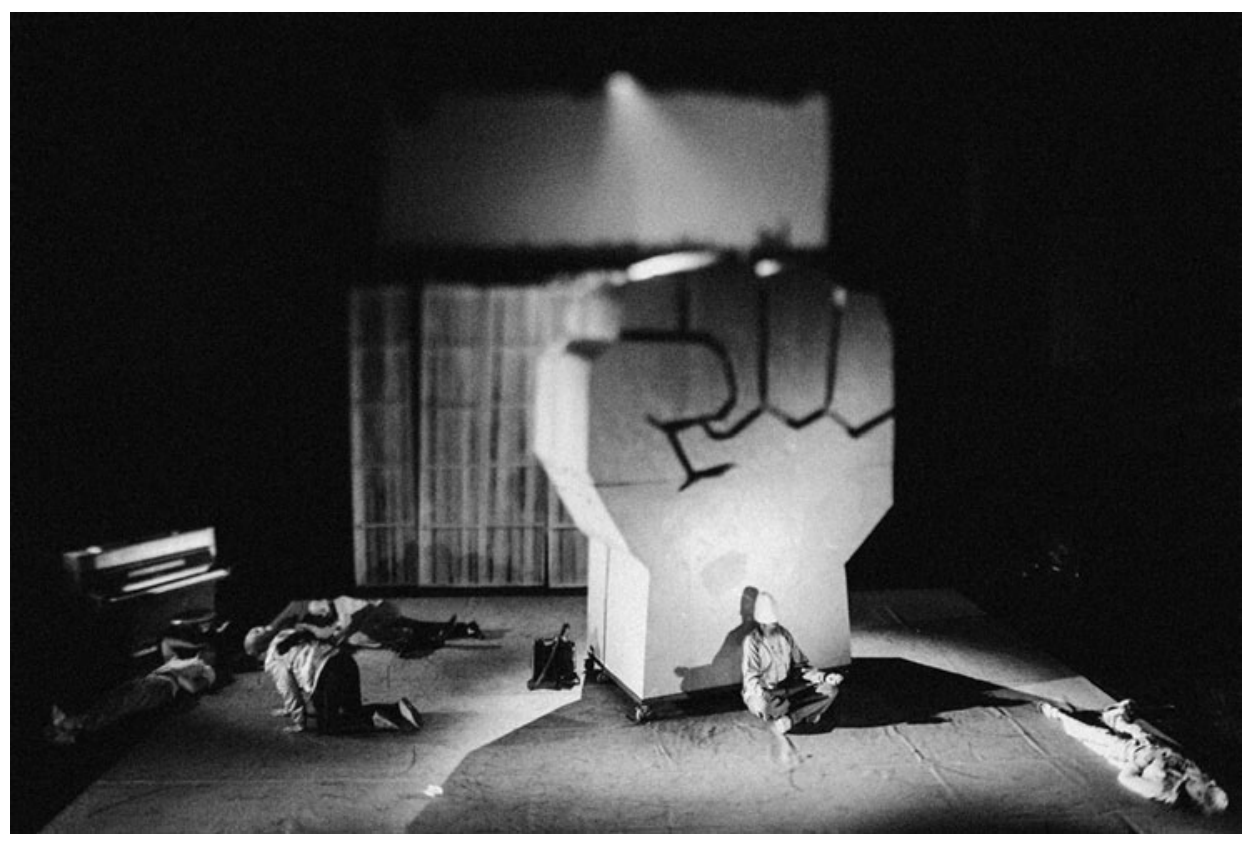

In Chevengur Jan Kačena mocks the numbing incapacity of revolutionaries. At the same time, he appreciates the mysterious power of utopia. This performance presents a vivid example of archetypal imagination. Andrey Platonov: Čevengur [Chevengur]. HaDivadlo, premiered on 25 May 2018. Direction Jan Kačena. Photo by Kateřina Barvířová.

Theatres represented (at least to a certain degree) a free space for speech. However is this mythology still of use? Or have the thirty years of building capitalism rewrite our experience and theatres have become a part of a neoliberal cultural empire anesthetized by capitalist realism - "a pervasive atmosphere" constraining thought and action $^{29}$

In the last decade, many projects declaring their radicality, social engagement and anti-neoliberalism have emerged in the Czech theatre. The Feste Theatre in Brno (founded in 2006 by director Jiří Honzírek), HaDivadlo in Brno (the theatre has been led by Ivan Buraj since 2015, who focuses on radical political dramaturgy), The Studio of Heroes in Prague (founded in 2012, led by Jan Horák) or Lachende Bestien in Prague (founded in 2011, led by Michal Hába) are some of the widely recognized theatre groups that aim to produce politically significant social critique. Even mainstream institutions sometimes produce performances striving for social critique, such as are the adaptations of Henrik Ibsen's Neprítel lidu [An Enemy of the People] (Theatre Komedie in Prague, 19. 1. 2019) or Dostoyevsky's Hráč [The Gambler] (The Goose on a String Theatre, 23. 10. 2018). Both performances were directed by Michal Hába, who is trying to establish himself as the leading director

and unusual "fusion of theatre and society." OSLZLÝ, P. On Stage with the Velvet Revolution. In The Drama Review, 1990, Vol. 34, Issue 3, pp. 97 - 108.

${ }^{29}$ FISHER, M. Capitalist Realism, p. 16. 
of the Czech leftist theatre. Artistically interesting is Ivan Buraj, who is more focused on ecology and as an artistic director, he promotes radical performances (for example the mystery adaptation of Andrey Platonov's Chevengur by Jan Kačena, HaDivadlo, 25. 9. 2018). Even though Buraj's rhetoric has always been educated and socially radical, his work was not explicitly socially radical until the performance Naši - Studie rozhovoru o klimatické krizi [My Folks - A Study of the Conversation about the Climate Crisis] (written by Ivan Buraj, Pavel Sterec, Bohdan Karásek, HaDivadlo, 31 January 2020). Nevertheless, his directional approach is endowed with noteworthy employment of a certain slowed time, depicting a distinctive void resembling the end of times.

As this evidence suggests, the Czech theatre professionals should speak publicly about the risks during the pandemic, even when they cannot perform because of the theatres' closure. They have access to media and can communicate their social critique. But the reality differs entirely from the expectations.

\section{Communicating the Crisis}

\section{1 The Vain Effort in the Lockdown}

On March 10, 2020, the Czech government banned all the theatre performances for an audience larger than 100 people. Later, the state of emergency was declared, and Czechia was "locked down". In this situation, the theatres addressed the problem of securing finances to survive economically and how (and what) to perform. For two months, the internet and media have become the main public sphere available for them; later, it was possible to perform on the streets while keeping social distance. Czech public television as well as private televisions such as was Mall. tv (\#kulturazije [hashtag "the culture is alive"]) broadcasted recordings of performances, some of the theatre institutions made available the online versions of their productions. The National Theatre in Prague, as well as few other theatres, provided some entertaining content, such as the Národní kurz šmíry [National Course of Low-Quality Art], made of simple sketches with popular actors. A few online discussions emerged, but their value and significance were low - usually being mere talk shows with celebrities (such as was Čtení ke kafi... [Coffee Break Reading...] by Bolek Polívka's Theatre). The most media attention was focused on the questions of the theatres' self-preservation and their public service, which in this case consisted of sewing DIY masks.

In April 2020, the owner of Theatre Broadway in Prague Oldřich Lichtenberg called upon the minister of culture Lubomír Zaorálek to resign. The reason was that, according to Lichtenberg, the minister favoured the public theatres when allocating the pandemic financial aid. Zaorálek responded that he was not surprised by the fact that Lichtenberg saw culture as a mere business. The Association of Independent Theatres supported the minister. The conflict has been preceded by a proclamation of another theatre managing director, Jan Hrušínský, who verbally attacked the government for closing the theatres. The issue highly resonated in the media and even the Czech president Miloš Zeman delivered a speech, in which he mentioned Hrušínský with disdain. 
Aside from these media affairs, the public space has not seen any significant public appearance of theatre professionals. ${ }^{30}$ During the pandemic, theatres have presented only minor endeavour to stimulate public discussion on the role of theatre in the society and to the values the professionals are devoted. The sole systematically organized project was a series of discussions about culture, politics and art produced by the National Theatre in Prague under the title \#kulturajenarod [hashtag "culture is the nation"]. ${ }^{31}$ Its character was entirely peripheral - it did not gain any media attention. The first of the discussion ("restart" with Lenka Havlíková, Martin Glaser and Petr Michálek, April 4, 2020) has 1549 views (in July 2020), the other of the fifteen videos have considerably less view - the first half of the series have had around 600 views, the last six around $300-400$ views $^{32}$ (despite the fact that the last episode featured an interview with the minister of culture. The declining numbers prove not only that the impact of such discussions can be very limited, but also that the series was not able to attract viewers from the field of theatre. The reason for the disinterest of the public in the project could be its rather poor quality and the shallow and unconvincing discussions.

Apart from this, minor critical statements by the theatre professionals appeared in Divadelní noviny [The Theatre Journal], ${ }^{33}$ focusing however on the issue of theatres' self-preservation. Only Host [The Guest Magazine] published an interview about ecology with Martin Sládeček (dramaturge of The Goose on The String Theatre in Brno), Barbora Gregorová (dramaturge of The National Theatre in Brno) and Ivan Buraj (the artistic director of HaDivadlo in Brno), ${ }^{34}$ yet this literary magazine targets a particular audience, and therefore it can hardly reach the general public. The interviews with the theatre professionals in mainstream media did not include any social criticism at all.

\footnotetext{
${ }^{30}$ In this essay, I rely on my own research, which partly relies on the information provided by the media database ANOPRESS, and partly consists of direct research in virtual space. I have searched for interviews with theatre professionals (directors, managers) during March-June 2020 in the Czech media (print, online news media, television and radio) and analysed the language of the material (the sample was 11 texts based on a thorough reading of all the outcomes of the database request). The analysis was based on Norman Fairclough's framework of critical discourse analysis. The presence of artists in media was observed through March-June in online space, at the websites of the theatres and online televisions and streaming platforms (YouTube) as well. All the examples presented in this essay were seen/read by the author and analysed in this manner. The March-June interval was selected both from the pragmatic reason (necessary reduction of the data) and because this interval covers the time the theatres were closed, or their operation was profoundly limited. I present my findings in the form of an essay because I aim to persuade and provide critical normative arguments. This is in accord with my intention to strengthen the view of humanities as therapy of humanity rather than science, as it was their classical function. See IKPE, I. B. The Decline of the Humanities and the Decline of Society. In Theoria: A Journal of Social and Political Theory, 2015, Vol. 62, Issue 142 , pp. $50-66$.

${ }^{31}$ [online]. [cit. 5 July 2020]. Available at: https://www.youtube.com/watch?v=LR8ywJo4ulo\&list=PLX4 BdqzB_vhPmgVr9uwLqPXRr-eygDCmH.

${ }^{32}$ The number of views can be an important hint of the public impact of the talk-shows. If the artists aim to spread their ideas, they can hardly rely only on the audience of their colleagues.

${ }^{33}$ The series of articles was called Theatres in the Quarantine.

34 ŠTĚPÁNEK, R. O klimatické krizi se musí mluvit bez nálepek a i v době koronaviru [The Climate Crisis must be Discussed without Labels and even in the Times of Coronavirus]. In Host, 2020, Vol. 36, Issue 5, p. 54 .
} 


\section{2 Presentation of Public Theatres in Media}

When we read the interviews with theatre directors in media during the crisis, we recognize that the representatives of public theatre ${ }^{35}$ hold the position of impartial managers, providing a public service. If they use the first-person singular voice, it is only to present either their modesty and humbleness ("I feel ashamed" - vis-à-vis the dedication of medical services, "I cannot sew" - i.e. masks), or to display their managerial decisiveness and vigour ("I myself deal with changes in the production"). The general voice is the first-person plural, which indicates that the directors see themselves as a part of the whole.

This impersonal and detached style of language underlines the administrative rhetoric resembling a talking about factory (the directors even use the verb "to manufacture"). The proliferation of active verbs depicting work or endeavour (theatre workers are "learning", "training", "doing their tasks", "planning", "preparing") resonates with the basic tone of industrial, not creative setting. What is to be done is "cleaning", "maintenance" or "reconstruction", activities usually performed by the lower classes of society.

Therefore, the managers usually do not forget to mention that they are "trying to be beneficial" and they take care not only of their employees and spectators, but of the societal needs as well - providing masks, support for schools or online amusement. This is closely related to the rhetoric of sobriety, diligence and hard work ("[the theatre institution] is housed in five different buildings, therefore the work is enough", "there is a lot of people who have more work than usual").

The managers avoid any discussion of the meaning and role of theatre in society. They articulate the values associated with theatrical art only unwittingly - saying that "theatre without spectators is a sad place", theatre is what people can "enjoy", "a visit to the theatre is a social event" and so on. There is a clear reluctance to reflect on the tasks of the theatre; the managers rather enumerate how they eliminate the financial losses. The theatre workers are always in a passive position towards the crisis, which just "happened". This is contrasted with their overall activity as if they are doing their best while only being victims. As Ulrich Beck assumes that "the risks and hazards are mediated on principle through argument", ${ }^{36}$ the managers did not recognize the crisis as being produced by the society they are part of; the pandemic is naturalized and without any questioning of the role of government or global economic, they back the government like its loyal servants - performing what political science calls "rally round the flag" in political science. ${ }^{37}$

\footnotetext{
${ }^{35}$ In my following argument, I include "radical" theatre artists as well, but because they were not represented in the media at all, there was nothing to analyse. The commercial theatre representatives' appearances were analysed too, but their speech was basically neoliberal. From this segment of art-world, no social criticism was expected, and therefore I disregard them in my reflections.

${ }^{36}$ BECK, U. Risk Society, p. 27.

${ }^{37}$ MUELLER, J. E. Presidential Popularity from Truman to Johnson. In The American Political Science Review, 1970, Vol. 64, Issue 1, p. 21.
} 


\section{Rethinking the Myth}

The question is: what has changed in Czech theatre that its speech now lacks social power? As Petr Oslzlý explains, the theatre generation which formed autorská divadla ("authorial" theatres) in the 1970s (Studio Y, Theatre on a String, HaDivadlo, Alfred Jarry Pantomime, Theatre on the Fringe or the Drama Studio in Ústí nad Labem) shared "a conscious desire to link up with the creative and intellectual currents of the 60's, the pre-war Czechoslovak democracy, with the humanitarian and cultural history of their nation, at a time when the totalitarian regime was disrupting this continuity and wiping out history." 38 The theatres represented an elitist intellectual opposition which was ready to help the revolution's dream come true when the historical opportunity emerged in 1989, and their speech was democratic in the sense of articulating political and artistic freedom and keeping the continuity of intellectual heritage, which was disrupted by the communist coup d'état in 1948 .

Even in the present-day neoliberal Czech society, the post-revolutionary sentiments are still alive. For instance, I have personally experienced the rejoicing audience at the opening night of the performance Listy Olze [Letters to Olga] (based on Václav Havel's letters to his wife, Theatre in Dlouhá Street, November 17, 2018) directed by SKUTR (Martin Kukučka and Lukáš Trpišovský). In the powerful atmosphere of the Velvet Revolution anniversary, one of the spectators was even shouting "Havel! Havel!" during the whole performance. The same "velvet" sentiments could be found in the anti-government public demonstrations of Czech actors, as I have mentioned before. However, today they correspond to the hegemonic ideology and can hardly possess any critical dynamics. As a technology of self-making, ${ }^{39}$ the neoliberalism incorporates individualization of responsibility and the claims of free speech or personal freedom (which were formerly radical in the totalitarian regime) are stale. Nowadays, the speech is free (even if it is a hate speech), but it does hardly mean that it is the true speech.

\section{1 Ideological Proletarianization}

Public theatres are, of course, funded by state or municipalities and eo ipso they need not be socially critical (although the participants of \#kulturajenarod YouTube series included the social criticism in their interpretation of public service). However, in the last years, it was possible to observe the profound growth of socially critical theatre. Therefore, one could hardly anticipate that in the crisis, the theatres would publicly articulate their meaning exclusively in terms of social utility and economic effectiveness, adapting the hegemonic neoliberal ideology ${ }^{40}$ However, even public theatres aim to preserve their institutional durée by disconnecting from political interests and often articulating their operation in economic and advertising terms ("all that is solid melts into

\footnotetext{
${ }^{38}$ OSLZLÝ, P. On Stage with the Velvet Revolution, p. 100.

${ }^{39}$ GANTI, T. Neoliberalism, pp. 95 - 96.

${ }^{40}$ I understand neoliberalism as a concept that differs from "late capitalism", not being a synonym. See GANTI, T. Neoliberalism, pp. 89 - 104. To this argument, I would like to add that in March-June period, I have not found any interview with any Czech theatre representative being socially critical.
} 
$\mathrm{PR}^{\prime \prime}$ as Mark Fisher says ${ }^{41}$ ). This is partly due to their necessary bureaucratic nature, partly because the disconnection from political interests is beneficial for maintaining their duration - the managers became ideologically proletarianized. ${ }^{42}$

As Charles Derber has explained, "[m]oral, social and technological issues are subtly removed from the purview of the worker, as [she] is deprived of control of [her] product and [her] relation to the larger community." 43 The reproduction of the social order is in the interest of the directors because it guarantees the state or municipal financial support and secures the future of their institution. The language of hard work, obligingness and sobriety serves this goal well.

\section{2 The "Radical" Silence}

When we focus on the more radical theatres and directors, even Michal Hába, who aspires to be a recognized left-wing artist, is unable to gain substantial attention from the general public and during the crisis, he remained entirely silent in the public sphere. Hába frequently refers to Bertolt Brecht's vision of socially relevant theatre, but his Enemy of the People or The Gambler resembled revues full of colourful, activist clichés and proclamations, torturing audience by its recurrence and superficiality. It is understandable that his work does not provoke the general public to political activities and lies below the limits of media attention. Another example: HaDivadlo, probably one of the artistically most interesting theatres in the contemporary Czechia, employs the same conceptual shallowness and elitism. Although the theatre's bulletins, posters and public appearances are radical and socially critical, they are incomprehensible for the general public being full of transcendentals - hackneyed phrases ("Anthropocene", "environmental sorrow", "the elements of growth's market mechanism" et cetera).

The leftist performers are not ideologically proletarianized and one can hardly say that they succumb to capitalist realism as public theatre representatives, but the "radical" speech is likewise comparably hollow, unable to reach a general audience. The language the directors use is elitist in the sense of globalized left-liberal jargon, partly resembling the neoliberal newspeak (multiculturalism, individualization, global trends et cetera). Employing the fashionable lexis of left-liberals, the speech barely mirrors any true human experience and socially relevant practice, being just a class habitus stacked full of transcendentals (concepts, dogmas). Why is such a language employed by the performers? Because of its utility. Being an instance of language commodification, i.e. the use of symbolic resources to add value to the performances as products ${ }^{44}$ for a small, elite group of leftist liberals (the profit from this "selling" is gaining the attention and becoming celebrities of this audience), it helps them to succeed in the artistic competition.

\footnotetext{
${ }^{41}$ Ibid., p. 39.

${ }^{42}$ On theatres as institutions preserving their durée see SHEEN, E. Shakespeare and the Institution of Theatre. New York : Palgrave Macmillan, 2009, p. 14; on ideological proletarianization see DERBER, Ch. Managing Professionals: Ideological Proletarianization and Post-Industrial Labor. In Theory and Society, 1983 , Vol. 12, Issue 3, pp. $309-341$.

${ }^{43}$ Ibid., p. 316.

${ }^{44}$ HELLER, M. The Commodification of Language. In Annual Review of Anthropology, 2010, Vol. 39, p. 110.
} 
In the Western world, this new liberal class was established during the 1960s and the 1970s by socio-economic shifts toward post-Fordist capitalism, absorbing many of the post-war rebellious dynamics, promoting new kind of consumerism. ${ }^{45}$ In Czechia, the emergence of this phenomenon can be linked to the rise of the Millennials in the last twenty years, and it is no wonder that the "radical" directors recruit from this cosmopolitan, well-educated and pop-culture generation (contrary to the directors of public theatres). Abandoning the notion of class and giving preference to the identity politics and progressivism, their ideology should not be confused with class-oriented socialism. In sociological terms, this social group can be characterized as the succeeding cosmopolitan class, encompassing $12 \%$ of Czech population and representing the future, global and fully modernized elite. On the contrary, the classes without satisfactory prospect (I call them "the outclassed") - the traditional working class and the suffering class - makes $32 \%$ of the Czech population and their lifestyle, education and skills can hardly compete with the future elite. ${ }^{46}$

Rather than to attract the general public and the outclassed, the theatre intellectuals strive for attention of the cosmopolitan art-world itself (securing or improving their artistic status guarantees their durée). The artistic field of production is highly competitive, the resources are scarce, and for success (or gaining attention) one has to acquire the fashionable "newspeak", "the new planetary vulgate", as Pierre Bourdieu and Loïc Wacquant say, "sweeping away the social and economic conquests of a century of social struggles". The new, individualized order is represented not only by conservatives and right-wing dinosaurs but also by cultural producers and left-wing activists "still think[ing] of themselves as progressivists". ${ }^{47}$ Who does not comply with the left-liberal language can be doomed to disregard or even excluded from the progressive apex of the art-world. ${ }^{48}$ The important question for the research and any socially relevant theatre practice is: What performances do the outclassed people attend if they visit the theatre at all? ${ }^{49}$

\section{3 The Subsidy Pragmatism}

Apart from this, many of the projects are constructed as (economically) pragmatic consideration based on some grant proposal. The theatres have to be able to give evidence of fulfilling the grant's indicators when asked. This neoliberal auditing culture mingles PR and bureaucracy "because the bureaucratic data is usually intended to

${ }^{45}$ GANTI, T. Neoliberalism.

${ }^{46}$ The amount of people is probably much larger, including the part of the endangered class (22\%). However, this class is inconsistently including people, who are only temporarily endangered, thus having the ability to enter the groups of prosperity. See PROKOP, D. et al. Rozděleni svobodou: Česká společnost po 30 letech [Divided by Freedom: Czech Society after 30 Years]. Praha : Radioservis, 2019, pp. 10 - 15.

${ }^{47}$ BOURDIEU, P. - WACQUANT, L. New Liberal Speak, p. 2. On the problem of "neoliberalization" of the left see MICHÉA, J.-C. Les Mystères de la gauche: de l'idéal des Lumières au triomphe du capitalisme absolu. Paris : Climats, 2013.

${ }^{48}$ This is the effect of "Vampire Castle", as described by Mark Fischer. See FISHER, M. Exiting the Vampire Castle. In OpenDemocracy, 24. 11. 2013. [online]. [cit. 24 August 2020]. Available at: https://www. opendemocracy.net/en/opendemocracyuk/exiting-vampire-castle/.

${ }^{49}$ The aforementioned research by Daniel Prokop et al. shows that the outclassed are "outcultured" as well. Their lifestyle is passive, education and language skills poor, and they are of higher age. See PROKOP, D. et al. Rozděleni svobodou, pp. 10 - 15. 
fulfil a promotional role." 50 Towards the artistic field of production, the theatre professionals have to present their appropriate cultural values and knowledge (even the "progressive" one) and cooperate with the appreciated personas to gain respect and attention. This holds true for both public and "radical" theatre artists.

The shallowness of the social criticism in Czech theatres is therefore based not only on ideological proletarianization or pragmatism but also on the structural problem of the artistic field. For many of the artists, the adaptation of left-liberalism is a strategy how to compete with the artistic rivals, gain the attention of reviewers or kindred journalists and obtain the funding from both national and foreign institutions pledging the hollow "socially critical" clichés. Their speech lacks profundity and analysis and is primarily oriented towards elites, which can provide resources. Therefore this "social criticism" is not sufficient vis-á-vis crisis, not mentioning the fact that it is engaged to attain the middle class, not the oppressed. This activism does not have the power to address the general public the way it was possible during the Velvet Revolution - and the silence during the crisis should be understood as the indifference to do anything more than securing the positions in the art-world. That is where the activists meet the directors of public theatres.

\section{To be Courageous Enough to Speak the Future}

In accord with the neoliberal shift of the 1980s towards a more individualized society based on personal responsibility even for the global risks (e. g. everyone is responsible for ecological harm), intellectuals are more and more cut off from the common discourse "and subjected to a high degree of competitive differentiation in their professional milieu". ${ }^{51}$ The artistic field of production seems to mirror this global intellectual incompetence to grasp the global issues in the terms appropriate for common negotiation and social recognition of the risks.

As François Laruelle explains, "[t]he future does not come out of some temporal transcendence, it comes from the depths of immanence" ${ }^{52}$ I would like to conclude that the inability of Czech theatre professionals to act in the times of crisis could be (at least partially) caused by this methodological failure. Intellectuals as activists have "a single language and single action at [their] disposal", ${ }^{53}$ which inhibits them from the adequate practice in crisis - because they lose the touch of particular reality and are prone to locking their speech in echo chambers. How to make the language able to bind people again?

We need to change our methodology and return to the origins of art as a shared imagination. I consider art being a hermeneutical event of "fusing horizons" in the sense of depth hermeneutics. The deep shared pre-semiotic archetypal background of humanity reveals the Real, sometimes suppressed in our reality, sometimes devaluated in the symbolic forms of ideology. This Real can address us all and being immanent, it transgresses the usual left-right and global-local dichotomies. It is "Terrestrial" in the sense of Bruno Latour's critical analysis of geopolitics, and therefore

\footnotetext{
${ }^{50}$ FISHER, M. Capitalist Realism, p. 50.

${ }^{51}$ BOURDIEU, P. - WACQUANT, L. New Liberal Speak, p. 4.

${ }^{52}$ LARUELLE, F. Intellectuals and Power, p. 129.

${ }^{53}$ Ibid., p. 122.
} 
it becomes a radically new political actor. ${ }^{54}$ Artists are qualified to "speak close by" (Laruelle) the archetypes and can use this skill to stimulate the utopic imagination. This skill cannot be taken for granted, rather it is gained in the process of individuation uniting conscious and unconscious forces of the artist. ${ }^{55}$ Therefore, the problem of contemporary incompetence of true speech should be seen as the problem of insufficient individuation of the artists who rely on the symbolic structures provided by the society and/or by the artistic field of production. Their speech is not rooted in their immanence (deep structures), but it sticks to the ideological (or "theoretical") surface. This is the startling paradox of the true individuation process, contrary to the mere individualization: in the depth of the differentiated individuality rests the shared collectivity.

As Martin Buber explains, every vision of utopia is grounded in the unconscious image of the desire for universality as "the longing for what is right and is to be experienced in a religious or philosophical view as a revelation or as an idea, and what by its nature cannot be realized individually, but only in the human community as such". ${ }^{56}$ The collective unconscious with its archetypal ground serves as the shared source for artists' work, and it possesses the raw (even dark) energy of the Real, which not only shows the inconsistencies of reality but also reveals the alternative for future for the general public. The artist uses images and symbols to reveal what is hidden. Being viscerally grounded in the collective unconscious, the artist's speech is able to transgress the gaps and discontinuities of transcendental concepts and show what is hidden under the cynicism of capitalism realism. When all the global rush of mobility, tourism, unsustainable business and factory production slows down because of the pandemic restrictions, the activist performers are called up to show how this new reality integrates the suppressed Real and can anticipate more sustainable and inclusive (Gemeinschaft) politics free of "realistic" utilitarianism. Besides the change of speech, this requires the virtue of courage as well: the courage to break out of the artistic field's competition and free oneself from the pragmatic logic of artistic opportunism.

\section{Translated by the author, edited by Klára Škrobánková}

\section{LITERATURE}

BECK, Dennis. C. Divadlo Husa na Provázku and the "Absence" of Czech Community. In Theatre Journal, 1996, Vol. 48, Issue 4, pp. 419 - 441. ISSN 0192-2882.

BECK, Ulrich. Risk Society: Towards a New Modernity. London : SAGE, 1992. 272 p. ISBN 9781446223420.

BENJAMIN, Stefanie - DILLETTE, Alana - ALDERMAN, Derek H. “We Can't Return to Normal": Committing to Tourism Equity in the Post-pandemic Age. In Tourism Geographies, 12. 5. 2020. DOI 10.1080/14616688.2020.1759130.

${ }^{54}$ LATOUR, B. Down to the Earth: Politics in the New Climate Regime. Medford : Polity Press, 2018, pp. $40-41$.

${ }_{55}^{5}$ JUNG, C. G. Bewusstsein, Unbewusstes und Individuation. In Die Archetypen und das Kollektive Unbewusste. Düsseldorf : Patmos - Walter, 2006, pp. $293-307$.

${ }^{56}$ BUBER, M. Pfade in Utopia, pp. $29-30$. 
BENNETT, Susan. Theatre/Tourism. In Theatre Journal, 2005, Vol. 57, Issue 3, pp. 407 - 428. ISSN 0192-2882.

BONCORI, Ilaria. The Never-ending Shift: A Feminist Reflection on Living and Organizing Academic Lives during the Coronavirus Pandemic. In Gender - Work-Organization, 15. 4. 2020. DOI 10.1111/gwao.12451.

BOURDIEU, Pierre - WACQUANT, Loïc. New Liberal Speak: Notes on the New Planetary Vulgate. In Radical Philosophy, 2001, Issue 105, pp. 2 - 5. ISSN 0300-211X.

BUBER, Martin. Elemente des Zwischenmenschlichen. In Das Dialogische Prinzip (ed. Martin Buber). Heidelberg : Lambert Schneider, 1984, pp. 271 - 298. ISBN 3-7953-0016-9.

BUBER, Martin. Pfade in Utopia: Über Gemeinschaft und deren Verwirklichung. Heidelberg : Lambert Schneider, 1985, 478 p. ISBN 3-7953-0187-4.

CHTIGUEL, Olga F. Without Theatre, the Czechoslovak Revolution Could Not Have Been Won. In The Drama Review, 1990, Vol. 34, Issue 3, pp. 88 - 96. ISSN 1054-2043.

COLLECTIF. La pandémie de Covid-19 est étroitement liée à la question de l'environnement. In Le Monde, 17. 4. 2020. [online]. [cit. 5 July 2020]. Available at: https://www.lemonde.fr/ idees/article/2020/04/17/la-pandemie-de-covid-19-est-etroitement-liee-a-la-question-de-1-environnement_6036929_3232.html.

CROSSLEY, Émilie. Ecological Grief Generates Desire for Environmental Healing in Tourism after COVID-19. In Tourism Geographies, 5. 5. 2020. DOI 10.1080/14616688.2020.1759133.

DERBER, Charles. Managing Professionals: Ideological Proletarianization and Post-Industrial Labor. In Theory and Society, 1983, Vol. 12, Issue 3, pp. 309 - 341. ISSN 0304-2421.

DOBUSCH, Laura - KREISSL, Katharina. Privilege and Burden of Im-/mobility Governance: On the Reinforcement of Inequalities during a Pandemic Lockdown. In Gender - Work - Organization, 2020, pp. 1 - 8. DOI 10.1111/gwao.12462.

DRIESSENS, Olivier. Celebrity Capital: Redefining Celebrity Using Field Theory. In Theory and Society, 2013, Vol. 42, Issue 5, pp. 543 - 560. ISSN 0304-2421.

EGEDE, Leonard E. - WALKER, Rebekah J. Structural Racism, Social Risk Factors, and Covid-19 - A Dangerous Convergence for Black Americans. In The New England Journal of Medicine, 22. 7. 2020. DOI 10.1056/NEJMp2023616.

FAIRCLOUGH, Norman. Language in New Capitalism. In Discourse \& Society, 2002, Vol. 13, Issue 2, pp. 163 - 166. ISSN 0957-9265.

FISHER, Mark. Capitalist Realism: Is There No Alternative? Winchester and Washington : Zero Books, 2009. 92 p. ISBN 978-1-84694-317-1.

FISHER, Mark. Exiting the Vampire Castle. In OpenDemocracy, 24. 11. 2013. [online]. [cit. 24 August 2020]. Available at: https://www.opendemocracy.net/en/opendemocracyuk/exiting-vampire-castle/.

GANTI, Tejaswini. Neoliberalism. In Annual Review of Anthropology, 2014, Vol. 43, pp. 89 - 104. DOI 10.1146/annurev.anthro.092412.155528.

HELLER, Monica. The Commodification of Language. In Annual Review of Anthropology, 2010, Vol. 39, pp. 101 - 114. DOI 10.1146/annurev.anthro.012809.1045951.

IKPE, Ibanga. B. The Decline of the Humanities and the Decline of Society. In Theoria: A Journal of Social and Political Theory, 2015, Vol. 62, Issue 142, pp. 50 - 66. DOI 10.3169/th.2015.6214203.

JAMESON, Frederic. Postmodernism, or, The Cultural Logic of Late Capitalism. Durham : Duke University Press, 1997. 460 p. ISBN 0-8223-0929-7.

Jiří Mádl oprášil svou výzvu: Zachraň bábu, zachraň dědka [Jiří Mádl Dusted Off his Challenge: Save the Grandma, Save the Grandpa]. In Seznam Zprávy, 17. 3. 2020. [online]. [cit. 5 July 2020]. Available at: https://www.seznamzpravy.cz/clanek/jiri-madl-oprasil-svou-vyzvu-zachran-babu-zachran-dedka-93824.

JUNG, Carl Gustav. Bewusstsein, Unbewusstes und Individuation. In Die Archetypen und das Kollektive Unbewusste. Düsseldorf : Patmos - Walter, 2006, pp. 293 - 307. 463 p. ISBN 3-53040084-X. 
KRÁL, Karel. Divadla jsou jako švábi: Anketa s nositeli Cen divadelní kritiky - a nejen s nimi [Theaters are Like Cockroaches: A Questionnare to the Theater Critics Award Winners and Not Just with Them]. In Svět a divadlo, 2020, Vol. 31, Issue 2, pp. 21 - 26. ISSN 0862-7258.

KURZMAN, Charles - OWENS, Lynn. The Sociology of Intellectuals. In Annual Review of Sociology, 2002, Vol. 28, pp. 63 - 90. DOI 10.1146/annurev.soc.28.110601.140745.

LACAN, Jacques. The Seminar of Jacques Lacan: Book II: The Ego in Freud's Theory and in the Technique of Psychoanalysis 1954-1955. New York - London : W. W. Norton \& Company, 1991, 300 p. ISBN 0-393-30709-3.

LATOUR, Bruno. Down to the Earth: Politics in the New Climate Regime. Medford : Polity Press, 2018, 140 p. ISBN: 978-1-5095-3057-1.

LAURENCIN, Cato T. - WALKER, Joanne M. A Pandemic on a Pandemic: Racism and COVID-19 in Blacks. In Cell Systems, 2020, Vol. 11, Issue 1, pp. 9 - 10. DOI 10.1016/j.cels.2020.07.002.

LAVOCAT, Lorène. Pour limiter les pandémies, les humains doivent «décoloniser le monde» [Enquête]. In Reporterre le quotidien de l'écologie, 28. 3. 2020. [online]. [cit. 5 July 2020]. Available at: https://reporterre.net/Pour-limiter-les-pandemies-les-humains-doivent-decoloniser-le-monde.

LARUELLE, François. Intellectuals and Power. Cambridge : Polity Press, 2015. 160 p. ISBN 9780-7456-6841-3.

LUKÁCS, Georg. Karl Marx und Friedrich Engels als Literaturhistoriker. Berlin : Aufbau Verlag, 1948. $247 \mathrm{p}$.

MICHÉA, Jean-Claude. Les Mystères de la gauche: de l'idéal des Lumières au triomphe du capitalisme absolu. Paris : Climats, 2013. 131 p. ISBN 978-2-08-129789-0.

MUELLER, John E. Presidental Popularity from Truman to Johnson. In The American Political Science Review, 1970, Vol. 64, Issue 1, pp. 18 - 34. ISSN 0003-0554.

Největší demonstrace od listopadu 1989? Letnou zaplnil protest za nezávislost justice [The Biggest Demonstration since November 1989? Letná was Filled with a Demonstration for the Independence of the Judiciary]. In iRozhlas, 23. 6. 2019. [online]. [cit. 5 July 2020]. Available at: https://www.irozhlas.cz/zpravy-domov/letna-demonstrace-andrej-babis-benesova-milion-chvilek-fotky_1906231735_lac.

OSLZLÝ, Petr. On Stage with the Velvet Revolution. In The Drama Review, 1990, Vol. 34, Issue 3, pp. 97 - 108. ISSN 1054-2043.

PROKOP, Daniel et al. Rozděleni svobodou: Česká společnost po 30 letech [Divided by Freedom: Czech Society after 30 Years]. Praha : Radioservis, 2019. 33 p. ISBN 978-80-88286-08-0.

SAID, Edward. Representations of the Intellectual. New York : Vintage, 1994. 144 p. ISBN 0-67976127-6.

SCAMBLER, Graham. COVID-19 as a 'Breaching Experiment': Exposing the Fractured Society. In Health Sociology Review, 2020, Vol. 29, Issue 2, pp.140-148. DOI 10.1080/14461242.2020.1784019.

SEGALOV, Michael. The Parallels between Coronavirus and Climate Crisis are Obvious [Interview]. In The Guardian, 4. 5. 2020. [online]. [cit. 5 July 2020]. Available at: https://www. theguardian.com/environment/2020/may/04/parallels-climate-coronavirus-obvious-emily-atkin-pandemic.

SHEEN, Erica. Shakespeare and the Institution of Theatre. New York : Palgrave Macmillan, 2009. 180 p. ISBN 978-0-230-52480-4.

STEVENS, Anthony. Archetype Revisited: An Updated Natural History of the Self. London - New York : Routledge, 2015. 386 p. ISBN 978-1-138-82468-3.

ŠTĚPÁNEK, Radek. O klimatické krizi se musí mluvit bez nálepek a i v době koronaviru [The Climate Crisis must be Discussed without Labels and even in the Times of Coronavirus]. In Host, 2020, Vol. 36, Issue 5, p. 54. ISSN 1211-9938. 
Jan Motal

Divadelní fakulta Janáčkovy akademie múzických umění

Mozartova 1

66215 Brno

Czech Republic

E-mail: motal@jamu.cz 